\title{
Article
}

\section{The Use of Peanut's Shells and Sawdust Absorbents for Reduced Iron (Fe) Levels of Dug Well Water Puspitaloka Residence Housing at Tanjungpinang City in 2019}

\section{Article Info}

\section{Article history :}

Received March 11, 2020

Revised March 18, 2020

Accepted April 22, 2020

Published April 30, 2020

Keywords :

Fe, Absorbent, Peanut's Shells, Sawdust

\section{Juliana $^{1 *}$, Hevi Horiza ${ }^{2}$, Rinaldi Daswito ${ }^{3}$}

Department of Sanitation, Health Polytechnic Tanjungpinang, Tanjungpinang, Indonesia

\begin{abstract}
Iron (Fe) levels in the dug well water of the community in Puspitaloka Residence Housing exceeded the quality standard so processing is needed to reduce the levels of iron contained in the dug well water. The purpose of this study was to determine the differences use of peanut's skin and sawdust absorbents to reduce levels of ferrous in dug well water. This study included pre-experimental research using the design of the one group pretest-posttest. The sampling technique was used in a purposive sampling method. Data analysis were Univariate and Bivariate analysis. Statistical tests used the Wilcoxon Signed Rank test and the Mann Whitney Test. The results showed a decrease in ferrous content using them. The presence of cellulose content in its had the potential to absorb iron. The results of the treatment the highest decrease, using peanut's shells absorbents occurred in the addition of 5 grams with a percentage of $54.41 \%$. While the treatment using sawdust absorbent, occurred at the addition of 10 grams with a percentage of $84.43 \%$. There was a difference the used of peanut's shells and sawdust absorbents to reduce iron levels in the water of the Puspitaloka Residence Housing dug well. Removal of dyes or bleaching on absorbents and reduce the level of turbidity to be considered to improve similar research.
\end{abstract}

This is an open acces article under the $\underline{C C-B Y}$ license.

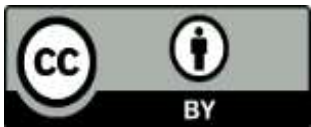

This is an open access article distributed under the Creative Commons 4.0 Attribution License, which permits unrestricted use, distribution, and reproduction in any medium, provided the original work is properly cited. (C2020 by author.

Corresponding Author :

Hevi Horiza

Department of Sanitation, Health Polytechnic Tanjungpinang,

Tanjungpinang, Indonesia

Email : hevi220987@gmail.com 


\section{Introduction}

Water is one of the natural resources that have a very important function in human life and other living things. This can be seen from the fact that $70 \%$ of the earth's surface is covered in water (Asmadi et al, 2011). According to the 2018 Riskesdas report, the proportion of water usage per person per day in the household, for the category of water usage is very less namely $<20$ litres/person/day is still $2.2 \%$ in Indonesia. While in the Riau Islands it is still $1.1 \%$ (Ministry of Health of the Republic of Indonesia, 2018). People in the world of $95 \%$ use groundwater as a source of clean water. But generally, groundwater contains very high metal ions (Joko and Rachmawati, 2016). Dug wells are one of the most common and widespread constructions of wells used to take groundwater for small communities and individual houses as clean water with a depth of 7-10 meters above ground level (Purba and Eko, 2013).

As many as $56 \%$ of Tanjungpinang city residents are dug well users, amounting to 146,976 inhabitants (Dinkes, 2018). The working area of Mekar Baru Health Center, most of the population uses dug wells as a means of obtaining water sources, which is $77 \%$, this is because this area has not received clean water services from the PDAM (Puskemas Mekar Baru, 2018). One of them is Puspitaloka Residence Housing, RT 002 RW 010 Batu IX Village, Tanjungpinang Timur District.

Based on the results of a preliminary survey conducted at the Puspitaloka Residential Housing, RT 002 RW 010 Batu IX Sub-District, Tanjungpinang Timur District, the researchers observed the brownish-yellow dug well water, formed an oil-like layer and smelled of rust and measured with the results of iron content analysis (Fe ) in the sample is $3.90 \mathrm{mg} / \mathrm{1}$. Judging from the Republic of Indonesia Minister of Health Regulation No. 32 the Year 2017 does not meet the requirements, the maximum level of iron $(\mathrm{Fe})$ allowed for water hygiene sanitation needs is $1 \mathrm{mg} / 1$.

To reduce metal content in water, many water treatment methods have been developed, such as precipitation, evaporation, electrochemical and resin usage techniques. These methods are considered ineffective because they require large costs for operation. Therefore, further tracing is carried out on new materials which are cheaper, easier to obtain and have a large adsorption power. Adsorption method is a promising method for separating heavy metals with low concentrations up to $1 \mathrm{mg} / \mathrm{L}$ (Suwalsih, 2011). Adsorbents that are often used to reduce levels of metals in the water generally come from waste, waste that can be used is cocoa skin, bark, candlenut shell, coffee skin, peanut shells and sawdust.

Peanut skins and sawdust are interesting wastes to be investigated as raw materials for making absorbents. This is because the content of peanut shells and sawdust contains components that play a role in the process of adsorption between heavy metals and absorbent from waste, which is a high cellulose content. The cellulose content in peanut shells is $63.5 \%$ and in sawdust is $49 \%$. The content is the presence of active groups that function to bind heavy metals in solution. The active group causes polar properties in the adsorbent. Thus, cellulose more strongly absorbs polar substances than less polar substances (Mandasari and Alfan, 2016). Utilization of peanut skin waste and wood sawdust as a raw material in the manufacture of absorbents is one alternative to reduce the volume of waste (Saputro and Dina, 2016).

Based on the description above, this study aims to determine the difference in the use of absorbent peanut skins and sawdust in reducing levels of iron metal $(\mathrm{Fe})$ in dug well water Puspitaloka Residence Housing in Tanjung Pinang City.

\section{Experimental Section}

\subsection{Tools and Materials}

The tools used in this study were bucket buckets, 5-litre jerry cans, bucket ropes, buckets, ovens, beaker glass, stopwatches, magnetic stirrers, filters, sieves, spatulas, blenders, analytical scales, Petri dish, sample bottles and 100 Merck Pharo Spectroquants. The materials used in this 
study are samples of well water, label paper, $\mathrm{pH}$ meter, infrared thermometer, turbidity meter, stationery, equates, $\mathrm{HNO}_{3}$, sawdust, peanut shells and Whatman filter paper.

\subsection{Methods Used}

\subsubsection{Absorbent Making Procedure}

In making this absorbent peanut skin under research Wulandari (2017): Prepare tools and materials to be used, peanut skin and sawdust cleaned by washing and then dried in the sun to dry under the sun, peanut shells and sawdust that has dried then mashed and sifted with a sieve, then soaked in $0.1 \mathrm{M} \mathrm{HNO}_{3}$ chemicals for 24 hours for activation. After that, filtered and washed with distilled water to neutral $\mathrm{pH}$. Furthermore, the oven absorbent peanut skin that has been activated at a temperature of $105^{\circ} \mathrm{C}$ for 8 hours.

\subsubsection{Implementation Procedure}

Prepare the tools and materials needed, digging well water samples before being treated using absorbent peanut skins and sawdust first tested the content of iron (Fe) in the Laboratory of PDAM Tirta Kepri Tanjungpinang, put well water into $100 \mathrm{ml}$ beaker glass, then, add 5 gram, 10 gram and 15-gram $\mathrm{HNO}_{3}$ chemical absorbent powder which has been activated using a $\mathrm{HNO}_{3}$ chemical solution into a beaker glass containing $100 \mathrm{~mL}$ of dug well water samples, insert the absorbent sawdust which has been activated using $\mathrm{HNO}_{3}$ chemical solution. as much as 5 grams, 10 grams and 15 grams into a container containing a sample of $100 \mathrm{~mL}$ dug well water, after which the stirring was carried out with a magnetic stirrer with a rotary speed of $100 \mathrm{rpm}$ for 240 minutes, then filtered using Whatman filter paper. and the filtrate is taken, input the treated water into the sample bottle and labelled, then the sample is measured Fe levels by analyzing the UV-Vis Spectrophotometer (Spectroquant Pharo 100 Merck) in the PDAM Tirta Kepri Tanjungpinang Laboratory. Repeat 2 times.

\section{Results and Discussion}

Univariate Analysis Results

Table 1 Decreased Iron Metal (Fe) Peanut Shells Absorbent

\begin{tabular}{|c|c|c|c|c|c|c|c|}
\hline \multirow{2}{*}{$\begin{array}{l}\text { Variation of } \\
\text { Absorbent Mass } \\
\text { Variation with } \\
\text { water samples }\end{array}$} & \multirow{2}{*}{$\begin{array}{l}\text { Initial Iron } \\
\text { (Fe) } \\
\text { content } \\
(\mathrm{mg} / \mathrm{l})\end{array}$} & \multicolumn{3}{|c|}{$\begin{array}{l}\text { Decreased Iron }(\mathrm{Fe}) \\
(\mathrm{mg} / \mathrm{L})\end{array}$} & \multirow{2}{*}{$\begin{array}{l}\text { Average } \\
\text { Decrease }\end{array}$} & \multirow{2}{*}{\multicolumn{2}{|c|}{$\begin{array}{l}\text { Percentage } \\
\text { Decrease }\end{array}$}} \\
\hline & & 1 & 2 & 3 & & & \\
\hline $5 \mathrm{gr}$ & & 1,07 & 1,18 & 1,09 & $1,11 \mathrm{mg} / \mathrm{L}$ & $54,41 \%$ & \\
\hline $10 \mathrm{gr}$ & 2,04 & 0,50 & 1,02 & 0 & $0,51 \mathrm{mg} / \mathrm{L}$ & $25,00 \%$ & \\
\hline $15 \mathrm{gr}$ & & 0 & 0 & 0 & $0 \mathrm{mg} / \mathrm{L}$ & $0 \%$ & \\
\hline
\end{tabular}

Based on table 2, the highest decrease of iron metal content $(\mathrm{Fe})$ in dug well water is on the decrease in iron metal content (Fe) after treatment using absorbent peanut shells with a mass variation of $5 \mathrm{gr}$ with an average decrease of $1.11 \mathrm{mg} / 1$ and the lowest decrease was in the decrease of iron $(\mathrm{Fe})$ metal content after the treatment using absorbent peanut shells with a mass variation of $15 \mathrm{gr}$ with an average decrease of $0 \mathrm{mg} / 1$ (no decrease).

Table 2: Decreased Iron Metal (Fe) Sawdust Absorbent

$\begin{array}{ccccc}\begin{array}{c}\text { Variation of Absorbent } \\ \text { Mass Variation with water } \\ \text { samples }\end{array} & \begin{array}{c}\text { Initial Iron } \\ (\mathrm{Fe})\end{array} & \begin{array}{c}\text { Decreased Iron }(\mathrm{Fe}) \\ \text { content }\end{array} & \begin{array}{c}\text { Average } \\ \text { Decrease }\end{array} & \begin{array}{c}\text { Percentage } \\ \text { of Decrease }\end{array}\end{array}$




\begin{tabular}{|c|c|c|c|c|c|c|}
\hline & $(\mathrm{mg} / \mathrm{l})$ & 1 & 2 & 3 & & \\
\hline $\begin{array}{l}5 \mathrm{gr} \\
10 \mathrm{gr} \\
15 \mathrm{gr} \\
\end{array}$ & 5,48 & $\begin{array}{l}3,70 \\
4,56 \\
4,50 \\
\end{array}$ & $\begin{array}{l}4,20 \\
4,66 \\
3,30 \\
\end{array}$ & $\begin{array}{l}4,22 \\
4,64 \\
1,83 \\
\end{array}$ & $\begin{array}{l}4,04 \mathrm{mg} / \mathrm{L} \\
4,62 \mathrm{mg} / \mathrm{L} \\
3,21 \mathrm{mg} / \mathrm{L}\end{array}$ & $\begin{array}{l}73,72 \% \\
84,33 \% \\
58,58 \% \\
\end{array}$ \\
\hline
\end{tabular}

Based on table 2, the highest decrease of iron metal content $(\mathrm{Fe})$ in dug well water is on the decrease in iron metal content $(\mathrm{Fe})$ after treatment using sawdust absorbent with a mass variation of $10 \mathrm{gr}$ with an average reduction of $4.62 \mathrm{mg} / 1$ and the lowest reduction was in the decrease in iron (Fe) metal levels after treatment using sawdust absorbent with a mass variation of 15 gr with an average reduction of $3.21 \mathrm{mg} / 1$.

\section{Bivariate Analysis Results}

\section{Difference in Iron (Fe) Metal Content Before and After Use of Peanut Absorbent}

To find out whether there are differences in levels of iron metal $(\mathrm{Fe})$ before and after the use of peanut shells absorbent in dug well samples in the Puspitaloka Residence Housing used Wilcoxon Signed Rank test. Presentation of data from the Wilcoxon Signed Rank test results on the use of absorbent peanut shells can be seen in the table as follows:

Table 3 Wilcoxon Signed Rank Test Use of Peanut Shells Absorbents

\begin{tabular}{lllll}
\hline Variabel & N & Mean Rank & Sum Of Ranks & P value \\
\hline After $<$ Before & 5 & 3,00 & 15,00 & \multirow{2}{*}{0,374} \\
After $<$ Before & 4 & 7,50 & 30,00 & \\
\hline
\end{tabular}

Based on the test results using a computer device the P-value of $0.374>0.05$ was obtained. Thus HO failed to reject, which means there is no difference in the levels of iron metal (Fe) before and after the use of absorbent peanut shells in dug well samples at the Puspitaloka Housing Residence.

\section{Differences in Iron (Fe) Metal Content Before and After Use of Sawdust Absorbents}

To find out whether there are differences in levels of iron metal $(\mathrm{Fe})$ before and after the use of sawdust absorbent in dug well samples in the Puspitaloka Housing Residence used the Wilcoxon Signed Rank test. Presentation of data from the Wilcoxon Signed Rank test results on the use of sawdust absorbent can be seen in the table as follows:

Table 4 Wilcoxon Signed Rank Test Use of Sawdust Absorbents

\begin{tabular}{lllll}
\hline Variabel & N & Mean Rank & Sum Of Ranks & $P$ value \\
\hline After $<$ Before & 9 & 5,00 & 45,00 & \multirow{2}{*}{0,008} \\
After $<$ Before & 0 & 0,00 & 00,00 & \\
\hline
\end{tabular}

Based on the test results using a computer device, the P-value of $0.008<0.05$ was obtained. Thus $\mathrm{HO}$ is rejected, which means there are differences in levels of iron metal $(\mathrm{Fe})$ before and after the use of sawdust absorbent in dug well samples at Puspitaloka Housing Residence..

\section{Difference in the Use of Peanut Absorbents and Sawdust in Reducing Iron (Fe) Metals}

To find out whether there is a difference in the use of peanut absorbent shells and sawdust in reducing levels of iron metal $(\mathrm{Fe})$ in dug well water Puspitaloka Residence Housing used the Mann Whitney test. Presentation of data from the results of Mann Whitney test differences in the use of absorbents can be seen in the table as follows: 
Table 5 Mann Whitney Test Differences in the use of absorbents

\begin{tabular}{lllll}
\hline Variabel & N & Mean Rank & Sum Of Ranks & Pvalue \\
\hline Peanut Shells & 9 & 5,00 & 45,00 & \multirow{2}{*}{0,001} \\
Sawdust & 9 & 14,00 & 126,00 & \\
\hline
\end{tabular}

Based on the test results using a computer device the results obtained by the value of the Mann Whitney $\mathrm{P}$ value of $0.001<0.05$. Thus $\mathrm{HO}$ is rejected which means there is a difference in the use of absorbent peanut shells and sawdust in reducing levels of ferrous metal $(\mathrm{Fe})$ in dug well water in Puspitaloka Housing Residence

\section{Dug Well Water Quality}

Residential Puspitaloka Residence, RT 002 RW 010 Kelurahan Batu IX, Tanjungpinang Timur District is a settlement that has land from swamp heaps. The physical water quality in the housing is yellowish, smelly metal or rust and chemically the water contains ferrous metal $(\mathrm{Fe})$ which does not meet clean water quality requirements based on the Republic of Indonesia Minister of Health Regulation No 32 of 2017 for water for sanitation hygiene, this is because the content ferrous metal $(\mathrm{Fe})$ obtained exceeds the allowable threshold value for ferrous metal $(\mathrm{Fe})$ which is 1.0 $\mathrm{mg} / 1$, while the metal content obtained is $2.04 \mathrm{mg} / 1$ and $5.48 \mathrm{mg} / 1$. Water samples were taken 2 times at different times, this is because the study was carried out 2 times for the use of absorbents using peanut shells and sawdust. The content of ferrous metals $(\mathrm{Fe})$ in 2 dug well water samples is different, this is due to differences in time when sampling is affected by the weather. The presence of high iron $(\mathrm{Fe})$ metal content in water is influenced by many things, namely water absorption depth, $\mathrm{pH}$, water temperature, aggressive iron bacteria and CO2 (Joko, 2010). So, before the water sample is treated, an examination of $\mathrm{pH}$, temperature and turbidity with a $\mathrm{pH}$ of 6.1 and 6.2 and a temperature of $35^{\circ} \mathrm{C}$ and $30^{\circ} \mathrm{C}$ and turbidity of $46 \mathrm{NTU}$ and $131 \mathrm{NTU}$

The Effect of the Use of Peanut Absorbents on Metal Iron Levels (Fe)

There is no difference in levels of iron metal $(\mathrm{Fe})$ before and after the use of absorbent peanut shells in dug well water Puspitaloka Residence Housing. This study does not prove that the sample that has been given the treatment has decreased levels of Iron (Fe), although based on the measurement results not all variations of the absorbent mass of peanut shells can not reduce iron levels $(\mathrm{Fe})$, but there is one variation of the shells absorbent mass Peanut that is a mass variation of 5 gr can reduce the level of iron (Fe) in the sample under the standard Permenkes RI No. 32 of 2017 for water sanitation hygiene needs that is the maximum limit of iron $(\mathrm{Fe})$ in water is $1 \mathrm{mg} / 1$.

This study is not in line with research conducted by Haikal et al (2016) about the use of adsorbent peanut shells as much as $100 \mathrm{gr} / 10 \mathrm{~L}$ of water with chemical activation can reduce levels of ferrous metals $(\mathrm{Fe})$ by $98.52 \%$ in 240 minutes contact with column systems. This research was conducted using a mass of 5 to 15 times greater than the absorbent mass of peanut shells carried out by Haikal et al (2016).

The greater the absorbent mass of the peanut shells, the lower the decrease in iron metal content $(\mathrm{Fe})$, but the process of reducing iron metal content $(\mathrm{Fe})$ can be stopped because of the saturation point. So that the levels of iron metal $(\mathrm{Fe})$ can increase after the treatment, especially in the absorbent mass of $10 \mathrm{gr}$ and 15 gr. According to Zunindra in Lestari (2012) suggested that the more absorbent used, the greater the pores on the absorbent surface. Besides the distance travelled by the surface of the water is also getting long in the process of absorption. However, if the absorbed ion concentration exceeds the maximum limit, it will result in saturation of the absorbent. When the absorbent surface is saturated or near-saturated with the adsorbate, two things can occur, namely the formation of a second absorption layer and so on above the absorbent that has been bound to the surface (multilayer absorption) or causes the adsorbate that has not been adsorbed to diffuse out of 
the pore and return to fluid flow. So it can be concluded that the use of absorbent peanut shells is better used in masses below $5 \mathrm{gr} / 100 \mathrm{ml}$ of water.

The absorption of ferrous metal $(\mathrm{Fe})$ using absorbent is influenced by several factors such as $\mathrm{pH}$. In this study, the $\mathrm{pH}$ of water treated using absorbent peanut shells decreased in $\mathrm{pH}$ to acid, even for mass variations of $10 \mathrm{gr} / 100 \mathrm{ml}$ and $15 \mathrm{gr} / 100 \mathrm{ml}$ the $\mathrm{pH}$ decreased to reach 4 . Then it can be concluded that the higher the absorbent mass variation the lower the $\mathrm{pH}$ in the sample. The decrease in $\mathrm{pH}$ in water samples can occur due to phenolic content in peanut shells (Win, 2011), this causes the content of $\mathrm{HNO}_{3}$ chemicals that are absorbed due to activation during washing using distilled water so that $\mathrm{pH}$ becomes normal is difficult to do.

The results of this study indicate the levels of iron metal $(\mathrm{Fe})$ have increased into the mass variation of $10 \mathrm{gr} / 100 \mathrm{ml}$ and $15 \mathrm{gr} / 100 \mathrm{ml}$ use of absorbent peanut shells compared to the iron metal content $(\mathrm{Fe})$ before being treated, this can occur due to a decrease in $\mathrm{pH}$ in water samples. Low $\mathrm{pH}$ is one of the things that affects iron solubility, low $\mathrm{pH}$ of the water will result in corrosive processes so that water can dissolve ferrous metals (Joko, 2010). The $\mathrm{pH}$ value is one of the most important parameters in the absorption process and can affect chemical equilibrium in the adsorbate or adsorbent. The absorption process decreases along with the decrease in $\mathrm{pH}$, it is caused by the ion exchange between adsorbent and adsorbate (Apriliani, 2010)

Absorbent peanut shells affects the level of turbidity in water, this is due to the process of adding absorbent peanut shells in the form of powder, so the more fine particles contained in the water, this causes the saturation of filter paper in filtering the particles. The more absorbent used, the more the burden of filtering water samples. For the parameters of $\mathrm{pH}$ and turbidity in water samples given absorbent peanut shells with some mass variations, none have met the water quality requirements based on Permenkes RI No. 32 of 2017 concerning environmental quality standards for water media for sanitary hygiene.

\section{Effect of Sawdust Absorbent Use on Iron (Fe) Metal Content}

There are differences in levels of iron metal $(\mathrm{Fe})$ before and after the use of absorbent sawdust in dug well water Puspitaloka Residence Housing. This research has proven that from the sample that has been given the treatment has decreased levels of Iron $(\mathrm{Fe})$, although only a variation of mass of $10 \mathrm{gr}$ absorbent sawdust can reduce iron levels (Fe) under the standard Permenkes RI No 32 of 2017 for water hygiene needs sanitation, namely the maximum limit of iron $(\mathrm{Fe})$ in water is $1 \mathrm{mg} / 1$.

This research is in line with research conducted by Munaroh (2018) that the reduction of Fe content in water can be carried out by the method of adsorption of sawdust with carbonization. The study modified the aerator bubble aerator method with contact time (15 minutes, 30 minutes, 60 minutes) and sawdust adsorption. The treatment using these methods each obtained an average decrease of $4.73 \mathrm{mg} / 1$ (92.20\%), $4.70 \mathrm{mg} / 1(91.61 \%), 4.67 \mathrm{mg} / 1(91,03 \%)$.

This study uses sawdust directly as an absorbent to reduce levels of ferrous metals (Fe) without carbonization and modification. Decrease in iron metal content $(\mathrm{Fe})$ based on variations in the mass of sawdust absorbent at a mass of $5 \mathrm{gr} / 100 \mathrm{ml}$ to $10 \mathrm{gr} / 100 \mathrm{ml}$, there was an increase in the absorption efficiency of ferrous metals $(\mathrm{Fe})$, but at a mass of $15 \mathrm{gr} / 100 \mathrm{ml}$ a decrease in absorption efficiency ferrous metal (Fe).

Increased absorption or absorption of iron $(\mathrm{Fe})$ metal content at 5 gr and 10 gr masses occurs due to the density of absorbent cells in solution to produce an effective interaction between the active centre of the absorbent cell wall and metal ions. The more absorbent substances, the more active centres of adsorbent react (Radyawati in Intan et al, 2016). So at 10 gr mass, the adsorption capacity is relatively high or reaches the optimum point because $\mathrm{OH}$ - ions in the solution are more abundant and the absorbent function group is negatively charged, so the competition of $\mathrm{H}^{+}$ions with metal ions is reduced in binding to the functional group of the absorbent. This causes more and more metals that can be adsorbed (Fatoni, 2009). Furthermore, the absorption of iron metal (Fe) is relatively decreased at the absorbent mass of 15 gr, this occurs because, at a higher absorbent mass, 
the amount of metal ions in solution is not proportional to the number of sawdust particles available so that the surface of the sawdust will reach the saturation point and efficiency absorption has also decreased (Saputro and Amelia, 2016).

Another factor that affects the absorption of ferrous metal $(\mathrm{Fe})$ using sawdust absorbent is $\mathrm{pH}$. The $\mathrm{pH}$ of the water after treatment using sawdust absorbent has increased in $\mathrm{pH}$, but the higher the absorbent mass used, the $\mathrm{pH}$ will also decrease. For mass variations of $5 \mathrm{gr} / 100 \mathrm{ml}$ and $10 \mathrm{gr} / 100$ $\mathrm{ml}$, absorbent sawdust can increase the $\mathrm{pH}$ of water samples that were not previously eligible to meet the requirements based on Permenkes RI No. 32 of 2017 concerning environmental health quality standards for water media for hygiene purposes sanitation namely 6.5-8.5.

In addition to changes in $\mathrm{pH}$, treatment using sawdust absorbent will affect the turbidity level in the water, the mass variation of $5 \mathrm{gr} / 100 \mathrm{ml}$ and $10 \mathrm{gr} / 100 \mathrm{ml}$ can reduce turbidity in water samples, but the mass of $15 \mathrm{gr} / 100 \mathrm{ml}$ causes an increase in turbidity. Of the various mass variations, no turbidity level in the water sample meets the requirements based on the Republic of Indonesia Ministerial Regulation Number 32 the Year 2017 regarding environmental health quality standards for water media for sanitation hygiene needs, namely 25 NTU.

\section{Differences in the Effect of the Use of Peanut Absorbents and Sawdust on Iron (Fe) Metals}

There is a difference in the use of absorbent peanut shells and sawdust in reducing levels of iron metal (Fe) in dug well water Puspitaloka Residence Housing. Absorbents used in this study were peanut shells and sawdust. The presence of cellulose content in peanut shells and sawdust has the potential to be used as a heavy metal absorbent. In this research, the use of the adsorption process is carried out with a stirring system, where absorption which is usually in the form of powder is added, mixed and stirred with water in a building so that there is a rejection between the absorbent particles and the fluid.

Cellulose has a large enough potential to be used as an absorber because the bound -OH group can interact with the adsorbate component. The presence of the $-\mathrm{OH}$ group in cellulose causes polar properties in the adsorbent. Thus cellulose more strongly absorbs polar substances than less polar substances. The absorption mechanism that occurs between the - $\mathrm{OH}$ group attached to the surface with the positively charged metal ion (cation) is the ion exchange mechanism as follows:

$$
\begin{gathered}
-\mathrm{Y}-\mathrm{OH}+\mathrm{M}^{+} \leftrightarrow-\mathrm{YO}-\mathrm{M}+\mathrm{H}^{+} \\
-\mathrm{Y}-\mathrm{OH}+\mathrm{M}^{2+} \leftrightarrow-\mathrm{YO}-\mathrm{M}-\mathrm{YO}-\mathrm{M}+2 \mathrm{H}^{+}
\end{gathered}
$$

$\mathrm{M}^{+}$and $\mathrm{M}^{2+}$ are metal ions, $-\mathrm{OH}$ is the hydroxyl group and $\mathrm{Y}$ is the matrix on which the $-\mathrm{OH}$ group is bound. The interaction between the $-\mathrm{OH}$ group and the metal ion is also possible through the mechanism of forming the coordination complex because the oxygen atom $(\mathrm{O})$ in the $-\mathrm{OH}$ group has a free electron pair, whereas the metal ion has $d$ empty orbitals. The pair of free electrons will occupy the empty orbitals owned by metal ions so that a complex compound or ion is formed (Harni et al, 2017).

The use of absorbent peanut shells with a mass variation of $5 \mathrm{gr}, 10 \mathrm{gr}$ and $15 \mathrm{gr}$ can reduce levels of ferrous metals by a percentage of $26.47 \%$, this is followed by the effect on water samples that are treated using absorbent peanut shells average $\mathrm{pH}$ to 4.7 so that the water sample has decreased $\mathrm{pH}$ to acid from before the treatment which has a $\mathrm{pH}$ value of 6.1 and increased the turbidity value to 502 NTU which before treatment was 46 NTU and decreased the temperature to $310 \mathrm{C}$ which was previously $35^{\circ} \mathrm{C}$. The use of absorbent sawdust with a mass variation of 5 gr, 10 gr and 15 gr can reduce levels of ferrous metals by a percentage of $72.26 \%$, the effect on water samples treated using sawdust absorbent is the average $\mathrm{pH}$ to 6.5 so that the sample water has increased $\mathrm{pH}$ to normal from before treatment by 6.2 and can increase the turbidity value to 197 NTU which before treatment was $131 \mathrm{NTU}$ and raise the temperature to $31^{\circ} \mathrm{C}$ which was previously $32^{\circ} \mathrm{C}$. 
Based on the percentage reduction in iron metal content $(\mathrm{Fe})$ in water samples, sawdust absorbent has a higher percentage than sawdust absorbent. This is because the adsorption is influenced by factors that support the absorption process of each absorbent that is used, these factors have different values so that measurements are needed such as optimum $\mathrm{pH}$, optimum contact time, optimum mass at each absorbent to get the value of decreasing metal content. effective in the use of absorbents. Cellulose content in peanut shells is $63.5 \%$ and cellulose content in sawdust is $49 \%$ but based on the results of decreased levels of iron metal $(\mathrm{Fe})$ is higher in absorbent sawdust, this is because the level of adsorption is influenced by other factors such as contact time, surface area, solubility of adsorbate, adsorbate molecular size, $\mathrm{pH}$ and temperature (Srining, 2001). Besides, the sawdust used in this study is mixed sawdust which allows the cellulose content in sawdust to vary in each wood.

Giving absorbent sawdust causes an increase in the $\mathrm{pH}$ of the sample so that it becomes normal, whereas in absorbent peanut shells causes a decrease in $\mathrm{pH}$ becomes more acidic. The decrease in $\mathrm{pH}$ after treatment using absorbent peanut shells can occur due to the presence of phenolic compounds in peanut shells, peanut shells containing phenolic compounds such as phydroxybenzoic acid, chlorogenic acid, ferulic acid, resveratrol, epicatechin and quercetin (Win, 2011). Phenols have limited solubility in water and have acidic properties, meaning they can release $\mathrm{H}+$ ions from their hydroxyl groups. The removal of these ions makes $\mathrm{C}_{6} \mathrm{H}_{5} \mathrm{O}^{-}$phenoxide anions which can be dissolved in water.

The use of absorbent peanut shells and sawdust can increase turbidity in dug well water. Turbidity can be caused by the presence of ash content and innate dyes in the shells of peanuts and sawdust. Greater ash content in peanut shells causes turbidity caused by absorbent peanut shells is higher than absorbent sawdust. Turbidity is caused by the presence of suspended and dissolved organic and inorganic materials, as well as inorganic materials in the form of plankton and other microorganisms (Asmadi et al, 201). Based on this description the use of absorbent sawdust is best for reducing levels of ferrous metal $(\mathrm{Fe})$ compared to the use of absorbent peanut shells.

\section{Conclusion}

Iron $(\mathrm{Fe})$ metal content before and after treatment by using absorbent peanut shells and sawdust with a mass variation (5 grams, 10 grams, 15 grams) obtained measurement values for before each of $2.04 \mathrm{mg} / 1$ and $5,48 \mathrm{mg} / 1$ and after each result the average yield is $0.93 \mathrm{mg} / 1,2.09 \mathrm{mg} / 1,4.51 \mathrm{mg} / 1$ and $1.44 \mathrm{mg} / 1,0.86 \mathrm{mg} / 1,2.27 \mathrm{mg} / 1$. Decreased levels of iron $(\mathrm{Fe})$ in the sample before and after being treated with absorbent peanut shells and sawdust with a variation of mass ( 5 grams, 10 grams, 15 grams) each obtained an average reduction of $1.11 \mathrm{mg} / 1(54.41 \%), 0.51 \mathrm{mg} / 1(25.00 \%), 0 \mathrm{mg} / 1$ $(00.00 \%)$ and $4.10 \mathrm{mg} / 1(74.82 \%), 4.62 \mathrm{mg} / 1(84.33 \%), 0 \mathrm{mg} / 1(58.58 \%)$. There is no difference in levels of iron metal $(\mathrm{Fe})$ before and after the use of absorbent peanut shells in dug well water Puspitaloka Residence Housing. There are differences in levels of iron metal (Fe) before and after the use of absorbent sawdust in dug well water Puspitaloka Residence Housing. There is a difference in the use of absorbent peanut shells and sawdust in reducing levels of iron metal (Fe) in dug well water Puspitaloka Residence Housing

\section{Acknowledgement}

I gratefully thank the principal of Health Polytechnic Tanjungpinang, Mr Novian Aldo, SST., MM for allowing me to conduct the research there. Also, thank For Tim research and the special one for my lecture Mrs Hevi Horiza and Rinaldi Daswito for allowing me to conduct my research. I could never have finished this without you.

\section{References}

[1] Asmadi, dkk. (2011). Teknologi Pengolahan Air Minum. Yogyakarta : Gosyen Publishing. 
[2] Budiman. (2011). Penelitian Kesehatan. Bandung : PT Refika Aditama.

[3] Dinas Kesehatan Kota Tanjungpinang. (2018). Akses Air Bersih Di Kota Tanjungpinang.

[4] Joko, T. (2010). Unit Produksi Dalam Sistem Penyediaan Air Minum. Yogyakarta : Graha Ilmu.

[5] Kementerian Kesehatan RI. (2018). Laporan Nasional Riskesdas 2018.

[6] Puskesmas Mekar Baru. (2018). Akses Air Bersih Wilayah Kerja Puskesmas Mekar Baru.

[7] Peraturan Menteri Kesehatan RI No. 32 Tahun (2017) Tentang Standar Baku Mutu Kesehatan Ligkungan Dan Persyaratan Kesehatan Air Untuk Keperluan Higiene Sanitasi, Kolam Renang, Solus Per Aqua, Dan Pemandian Umum.

[8] Apriliani, Ade. (2010). Pemanfaatan Arang Ampas Tebu Sebagai Adsorben Ion Logam Cd, $\mathrm{Cr}, \mathrm{Cu}$ dan $\mathrm{Pb}$ Dalam Air Limbah. Jakarta : Universitas Islam Negeri Syarif Hidayatullah.

[9] Fatoni, A. (2009). Adsorpsi Ion Logam Kadmium Oleh Adsorben Sabut Kelapa Dan Sabut Kelapa-2 Merkaptobenzotiazol: (Pengaruh Ph). Jurnal Kimia Mulawarman, 7(2), 19-22.

[10] Haikal, M dkk. (2016). Penggunaan Adsorben Kulit Kacang Tanah Untuk Penyisihan Logam Besi (Fe) Dan Mangan (Mn) Dalam Air Dengan Menggunakan Sistem Kolom. Jurnal Reaksi Jurusan Teknik Kimia Politeknik Negeri Lhokseumawe Vol. 14 No. 01.

[11] Harni, M.R dkk. (2017). Pemanfaatan Serbuk Gergaji Kayu Jati (Tectona Grandis L.F.) Sebagai Adsorben Logam Timbal (Pb). Bogor : FMIPA Universitas Pakuan.

[12] Intan, dkk. (2016). Pemanfaatan Biomassa Serbuk Gergaji Sebagai Penyerap Logam Timbal. Palu : Universitas Tadulako.

[13] Joko,T dan Rachmawati S. (2016). Variasi Penambahan Media Adsorpsi Kontak Aerasi Sistem Nampan Bersusun (Tray Aerator) Terhadap Kadar Besi (Fe) Air Tanah Dangkal di Kabupaten Rembang. Universitas Diponegoro.

[14] Lestari. (2012). Pemanfaatan Serbuk Eceng Gondok Untuk Menurunkan Kadar Cadmium (Cd) Pada Air Sumur Gali Masyarakat Didesa Namo Bintang Kecamatan Pancur Batu Kabupaten Serdang. Universitas Sumatera Utara hal 2-5.

[15] Mandasari, I dan Alfan P. (2016). Penurunan Ion Besi (Fe) dan Mangan (Mn) dalam Air dengan Serbuk Gergaji Kayu Kamper. Jurnal Teknik ITS Vol. 5, No. 1.

[16] Munaroh. (2018). Modifikasi Metode Aerasi Bubble Aerator Dan Adsorpsi Serbuk Gergaji Dalam Menurunkan Kadar Logam Besi (Fe) Pada Air Sumur Gali Tahun 2018. Karya Tulis Ilmiah Poltekkes Kemenkes Tanjungpinang.

[17] Purba, M.F.D dan Eko H. (2013). Penurunan Kandungan Zat Besi (Fe) dalam Air Sumur Gali dengan Metode Aerasi. Semarang : Universitas Dian Nuswantoro.

[18] Saputro, S dan Amelia R. (2016). Penggunaan Serbuk Gergaji Kayu Jati (Tectona Grandis L.F) Sebagai Adsorben Ion Logam Cd(II) Dan Analisisnya Menggunakan Solid-Phase Spektrophotometry (SPS). Surakarta : FKIP Universitas Sebelas Maret.

[19] Saputro, S dan Dina F. (2016). Aplikasi Karbon Aktif Dari Serbuk Gergaji Kayu Jati (Tectona Grandis L.F.) Sebagai Adsorben Ion Logam Pb(II) Dan Analisisnya Menggunakan Solid-Phase Spectrophotometry (SPS). Surakarta : FKIP Universitas Sebelas Maret.

[20] Srining, P. (2001). Perbedaan penurunan kadar zat warna dengan media adsorbsi karbon aktif tempurung kelapa, Kulit Kacang Pada Industri Batik Roro Djonggrang. Yogyakarta : Universitas Sebelas Maret.

[21] Suwalsih. (2011). Sintesis Zeolit A Dari Abu Dasar Batubara Dan Aplikasinya Sebagai Adsorben Ion Ni(II). Thesis. Yogyakarta : FMIPA Universitas Gadjah Mada.

[22] Win, dkk. (2011). Phenolic Compounds And Antioxidant Activity Of Peanut's Skin, Hull, raw Kernell and Roasted Kernel Flour. Pak j Bot 43(3).

[23] Wulandari, R dan Budi U. (2017). Adsorpsi Ion Mangan (II) Dengan Adsorben Kulit Kacang Tanah (Arachis Hypogea L.) Kombinasi Bonggol Jagung (Zea Mays L.) Teraktivasi 